\title{
Seroprevalence of Bovine Brucellosis and its Public Health Significance in Central High Land of Ethiopia
}

\section{Temesgen Kassa Getahun ( $\square$ Temesgen.kassa@eiar.gov.et )}

Ethiopian Institute of Agricultural Research

\section{Gezahegn Mamo}

Addis Ababa University

\section{Beksisa Urge}

Ethiopian Institute of Agricultural Research

\section{Research Article}

Keywords: Abortion, Bovine Brucellosis, Human Brucellosis, Risk factors, Seroprevalence

Posted Date: June 28th, 2021

DOI: https://doi.org/10.21203/rs.3.rs-658842/v1

License: (c) (1) This work is licensed under a Creative Commons Attribution 4.0 International License. Read Full License 


\section{Abstract}

Background: Brucellosis is a serious zoonotic disease affecting human and all domestic animals. It is considered to be one of the great public health problems all over the world. Little attention has been paid to bovine brucellosis in small holder dairy farm and in animal owners and farm workers in central highland of Ethiopia.

Result: The overall seroprevalence of bovine brucellosis were $1.2 \%(95 \% \mathrm{Cl}: 0.47-2.97)$ by RBPT alone and 0.6\% (95\% Cl: 0.016-2.09) using combined RBPT and CFT tests. In human, the overall seroprevalence of zoonotic brucellosis was $4.2 \%$ (95\%Cl: $0.204-8.42)$ by RBPT and $1.2 \%(95 \% \mathrm{Cl}$ : $0.032-4.27)$ using combined RBPT and CFT tests. Statistical analysis of risk factors by univariable firth's bias reduced logistic regression indicates that late stage of abortion $(O R=14.74, p=0.0002)$, retained fetal membrane $(\mathrm{OR}=32.74, \mathrm{p}=0.006)$, market based stock replacement $(\mathrm{OR}=16.55, \mathrm{p}=0.002)$, and presence of parturition pen $(\mathrm{OR}=11.511, \mathrm{p}=0.027)$ were found to be significantly associated with the seropositivity for Brucella infection in dairy cattle. The seropositivity of human brucellosis was significantly influenced by human housing $(O R=1.8, p=0.002)$, contact with aborted fetus $(O R=21.19, p=0.017)$, drinking raw milk from aborted $(O R=5.72,0.019)$ and retained fetal membrane $(O R=4.22, p=0.029)$ cows. A structured interview question was administered to 284 respondents. Accordingly, most respondents had no knowledge on brucellosis $(93.3 \%)$.

Conclusion: The present seroprevalence study revealed that brucellosis is prevalent at lower rate among dairy cattle and in exposed individuals in the study areas. However, since there were no control strategies implemented in the area, there is a potential risk for transmission of brucellosis in dairy cattle and exposed human population of study areas. With the low prevalence of bovine brucellosis in government owned and small holder farms, implementation of test and slaughter strategy with compensation to farmers is recommended; while in case of human brucellosis, continuous social training with feedback assessments, implementing one health approach framework and since its presence is confirmed and the risk factors are identified, the medical personnel should give attention as to differential diagnosis of the disease which has been overlooked so far.

\section{Background}

Brucellosis is a contagious and economically important bacterial disease of animals worldwide and it is considered as one of the neglected zoonoses in the world. It has been virtually eliminated from the majority of the developed countries, but it is still endemic in Africa [1]. The genus Brucella consists of commonly known six classically recognized species based on antigenic/biochemical characteristics and primary host species: $B$. abortus (cattle), B. melitensis (sheep and goats), $B$. suis (swine, cattle, rodents, wild ungulates), $B$. ovis (sheep), B. canis from dogs and $B$. neotomae of rodents [2].

Bovine brucellosis is an infectious and contagious disease and is predominantly a disease of sexually mature animals which usually caused by $B$. abortus, occasionally by $B$. melitensis and $B$. suis. It affects 
approximately $5 \%$ of the livestock population worldwide. The disease poses a barrier to trade of animals and animal products, represents a public health hazard, and is an impediment to free animal movement. Economic loss due to delayed heat, loss of calves, reduced milk production, culling and economic losses from international trade bans in tropics and subtropics [3] (WHO, 2001).

In cattle the mode of transmission is usually from animal to animal by contact following an abortion and retained placenta. Pasture or animal barn may be contaminated and the organisms are most frequently acquired by ingestion but also inhalation and conjunctival inoculation are other possibilities. The use of pooled colostrum for feeding newborn calves may also transmit infection. Sexual transmission usually plays little role in the epidemiology of bovine brucellosis. However, artificial insemination can transmit the disease and semen must only be collected from animals known to be free of infection [3].

Brucellosis is the second most important zoonotic disease in the world after rabies. Brucellosis in human known as "undulant fever", "Mediterranean fever" or "Malta fever" and the infection is almost invariably transmitted by direct or indirect contact with infected animals or their products. B. melitensis, B. abortus and $B$. suis are zoonotic pathogenic species [64]. It affects people of all age groups and of both sexes. Human clinical disease is characterized by severe flu-like illness, a high recurrent fever, arthritis and internal organs (heart failure) [4].

Human can acquire brucellosis by contact with infected tissues, blood, urine, vaginal discharges, aborted animal foetuses and especially placentae. It can also be transmitted by inhalation of aerosols which may occur in animal pens and stables, abattoirs and laboratories. A small number of cases have occurred following accidental self-inoculation of the strain 19 animal Brucella vaccine [3].

In Ethiopia there is no documented information on how and when bovine brucellosis was introduced and established. However, in the last two decades several serological surveys have showed that it is endemic and widespread $[5,6]$. The disease is prevalent in cattle in high land and lowland areas $[7,8,35]$. Even though a large number of studies on bovine brucellosis have been reported in different part of the country, studies conducted on the role of bovine brucellosis in relation to public health significance in occupational exposed individuals are limited in intensive and extensive production systems $[9,10]$.

Though there is limited information on the seroprevalence of bovine brucellosis in some farms in Holeta Town, no previous seroprevalence report of brucellosis in small holder dairy cattle and in exposed farm owner and farm employees found in smallholder and government owned farm in Holeta Town, Walmera District and Ethiopian Institute of Agricultural Research (EIAR) Holeta Agricultural Research Center (HARC) Adda Berga dairy farm which are located in the milk-shed areas for Addis Ababa and its surrounding. In addition, assessment of the status of the disease and understanding of the awareness among the community has paramount importance in order to identify the risk factors for infection and zoonotic transmission to design appropriate measures to reduce the public health significance of brucellosis. Therefore, this study was carried out with the following objectives: 
- To determine the current seroprevalence status of brucellosis in bovine with recent history of abortion in the study area.

- To determine the seroprevalence of brucellosis in animal owners and government farm employees.

- To assess the associated risk factors of bovine and human brucellosis in the study area.

- To assess knowledge, attitude and practice of animal owners and government farm employees in relation to zoonotic brucellosis.

\section{Result}

Seroprevalence of Brucellosis in Dairy Cattle

The present study revealed that out of 352 dairy cows with history of recently abortion tested (222 cross and 130 local breed), 4 (1.2\%) (95\% Cl: 0.0047-0.0297) were tested positive by RBPT. The RBPT positive serum samples were further tested using CFT for confirmation. Only 2 samples ware confirmed seropositive for bovine brucellosis in the study area. The overall seroprevalence of bovine brucellosis were thus $0.6 \%$ (95\% Cl: $0.0016-0.0209)$ based on CFT tests in the study area (Fig. 1).

Association of putative risk factors with bovine brucellosis seropositivity

Univariable Firth's Bias-Reduced Logistic Regression analysis was computed to evaluate the association between brucellosis seropositivity and different risk factors. Out of 352 serologically screened dairy cows, $1(0.3 \%)$ from Ethiopian Institute of Agricultural Research Holeta Agricultural Research Center (HARC) large scale dairy farm, $1(0.3 \%)$ from Fayiru medium scale farm and 2(0.6\%) from Burka Harbu kebele were positive by RBPT and 2(0.6\%) from Burka Harbu kebele were further confirmed by CFT. The analysis indicates that there was no statistically significant association between animal origins and bovine brucellosis $(P>0.05)$ (Table 1$)$. 
Table 1

Univariable Firth's Bias-Reduced Logistic Regression analysis of risk factors associated with bovine brucellosis seropositivity

\begin{tabular}{|c|c|c|c|c|c|}
\hline \multirow[t]{2}{*}{ Variables } & \multirow{2}{*}{$\begin{array}{l}\text { No. of cows } \\
\text { sampled }\end{array}$} & \multicolumn{2}{|c|}{ No. positive } & \multirow[t]{2}{*}{ OR(95\%Cl) } & \multirow[t]{2}{*}{ P-Value } \\
\hline & & $\begin{array}{l}\text { RBPT } \\
\text { (\%) }\end{array}$ & $\begin{array}{l}\text { CFT } \\
(\%)\end{array}$ & & \\
\hline \multicolumn{6}{|l|}{ Origin/Site } \\
\hline $\begin{array}{l}\text { Adea Berga } \\
\text { farm }\end{array}$ & 30 & 0 & 0 & 1.0 & \\
\hline Holeta Town & 163 & $4(1.2)$ & $2(0.6)$ & $\begin{array}{l}1.944(0.0744- \\
13.1495)\end{array}$ & 0.97 \\
\hline Wolmera & 159 & 0 & 0 & $1.912(1.0271-35.596)$ & 0.4334 \\
\hline \multicolumn{6}{|l|}{ Herd size } \\
\hline Large scale & 58 & $1(0.3)$ & 0 & 1.0 & \\
\hline Medium scale & 40 & $1(0.3)$ & 0 & $1.44(0.7754-2.6907)$ & 0.8552 \\
\hline Small holders & 254 & $2(0.6)$ & $2(0.6)$ & $\begin{array}{l}1.158(9.2643- \\
60.6058)\end{array}$ & 0.923 \\
\hline \multicolumn{6}{|l|}{ Breed } \\
\hline Cross & 222 & $3(0.9)$ & $1(0.3)$ & 1.0 & \\
\hline Local & 130 & $1(0.3)$ & $1(0.3)$ & $1.71(0.137-21.224)$ & 0.645 \\
\hline \multicolumn{6}{|l|}{ Age } \\
\hline Young & 78 & $1(0.3)$ & $2(0.6)$ & 1.0 & \\
\hline Adult & 233 & $2(0.6)$ & 0 & $3.356(0.269-42.767)$ & 0.312 \\
\hline Old & 41 & $1(0.3)$ & 0 & $9.245(0.061-18.527)$ & 0.274 \\
\hline \multicolumn{6}{|l|}{ Parity status } \\
\hline Primipareous & 57 & $1(0.3)$ & $1(0.3)$ & 1.0 & \\
\hline Pluripareous & 295 & $3(0.9)$ & $1(0.3)$ & $5.212(0.417-65.049)$ & 0.176 \\
\hline \multicolumn{6}{|c|}{ Stage of abortion } \\
\hline Late Sage & 13 & $3(0.9)$ & $2(0.6)$ & $14.76(1.1211-2.042)$ & $0.0002^{\star \star \star}$ \\
\hline Early stage & 339 & $1(0.3)$ & 0 & 1.0 & \\
\hline
\end{tabular}

*=statistically significant, $\mathrm{OR}=$ Odds ratio, $\mathrm{Cl}=$ Confidence interval 


\begin{tabular}{|c|c|c|c|c|c|}
\hline \multirow[t]{2}{*}{ Variables } & \multirow{2}{*}{$\begin{array}{l}\text { No. of cows } \\
\text { sampled }\end{array}$} & \multicolumn{2}{|c|}{ No. positive } & \multirow[t]{2}{*}{$\mathrm{OR}(95 \% \mathrm{Cl})$} & \multirow[t]{2}{*}{ P-Value } \\
\hline & & $\begin{array}{l}\text { RBPT } \\
\text { (\%) }\end{array}$ & $\begin{array}{l}\text { CFT } \\
(\%)\end{array}$ & & \\
\hline Government & 1 & 0 & 0 & 1.0 & \\
\hline Own source & 198 & $3(0.9)$ & $1(0.3)$ & $0.431(2.326-7.974)$ & 1.000 \\
\hline $\begin{array}{l}\text { Market } \\
\text { purchase }\end{array}$ & 16 & $1(0.3)$ & $1(0.3)$ & $16.548(8.436-24.612)$ & $0.0022^{\star *}$ \\
\hline Both & 52 & 0 & 0 & $4.981(2.607-7.324)$ & 0.143 \\
\hline \multicolumn{6}{|l|}{ Hygiene of barn } \\
\hline Poor & 111 & $2(0.6)$ & $2(0.6)$ & $4.635(3.713-64.2)$ & 0.256 \\
\hline Medium & 140 & $2(0.6)$ & 0 & $0.722(3.902-133.75)$ & 0.871 \\
\hline Good & 101 & 0 & 0 & 1.0 & \\
\hline \multicolumn{6}{|l|}{ Type of farming } \\
\hline Intensive & 32 & 0 & 0 & 1.0 & \\
\hline Extensive & 164 & $1(0.3)$ & $1(0.3)$ & $1.564(8.272-22.933)$ & 0.776 \\
\hline Semi-intensive & 156 & $3(0.9)$ & $1(0.3)$ & $3.638(19.105-53.43)$ & 0.394 \\
\hline \multicolumn{6}{|l|}{ RFM } \\
\hline Yes & 48 & $4(1.2)$ & $2(0.6)$ & $32.74(2.611-4.544)$ & $0.0063^{\star *}$ \\
\hline No & 304 & 0 & 0 & 1.0 & \\
\hline \multicolumn{6}{|l|}{ Mating practice } \\
\hline $\mathrm{Al}$ & 137 & 0 & 0 & 1.0 & \\
\hline Natural mating & 80 & $4(1.2)$ & $2(0.6)$ & $7.581(0.609-1.049)$ & $0.05^{\star}$ \\
\hline Both & 135 & 0 & 0 & $2.095(1.131-3.882)$ & 0.715 \\
\hline \multicolumn{6}{|c|}{ Presence of parturition pen } \\
\hline Yes & 7 & $2(0.6)$ & 0 & 1.0 & \\
\hline No & 260 & $2(0.6)$ & $2(0.6)$ & $11.533(0.0604-0.22)$ & $0.027 *$ \\
\hline \multicolumn{6}{|c|}{ Separation of cow during parturition } \\
\hline yes & 335 & $4(1.2)$ & $2(0.6)$ & 1.0 & \\
\hline No & 17 & 0 & 0 & $0.262(0.02-26.72)$ & 0.461 \\
\hline
\end{tabular}

*=statistically significant, $\mathrm{OR}=$ Odds ratio, $\mathrm{Cl}=$ Confidence interval 


\begin{tabular}{|c|c|c|c|c|c|}
\hline \multirow[t]{2}{*}{ Variables } & \multirow{2}{*}{$\begin{array}{l}\text { No. of cows } \\
\text { sampled }\end{array}$} & \multicolumn{2}{|c|}{ No. positive } & \multirow[t]{2}{*}{$\mathrm{OR}(95 \% \mathrm{Cl})$} & \multirow[t]{2}{*}{ P-Value } \\
\hline & & $\begin{array}{l}\text { RBPT } \\
(\%)\end{array}$ & $\begin{array}{l}\text { CFT } \\
(\%)\end{array}$ & & \\
\hline \multicolumn{6}{|c|}{ Cleaning of calving area after parturition } \\
\hline No & 280 & $3(0.9)$ & $2(0.6)$ & $0.768(0.554-9.57)$ & 0.861 \\
\hline Yes & 72 & $1(0.3)$ & 0 & 1.0 & \\
\hline
\end{tabular}

The seroprevalence of bovine brucellosis in late stage of abortion ( $O R=14.76, p=0.0002)$, retained fetal membrane $(O R=32.74, p=0.0064)$, market source of stock replacement $(O R=16.548, p=0.0022)$, natural breeding method $(O R=7.581, p=0.05)$ and parturition pen $(O R=11.533, p=0.027)$ were statistically significant while other factors were not statistically significant $(P>0.05)$ (Table 1$)$.

The seroprevalence of local and cross breed cows was $0.3 \%$ for each and there were no statistically significant association between brucellosis seroprevalence and breeds $(P>0.05)$. According to the result of this study age categories were not significantly associated with bovine brucellosis. Even though no statistically significant association with age groups, there were higher seroprevalence $(0.6 \%)$ of bovine brucellosis in cows with young age compared to animals with adult. Seropositivity in primipareous and pluripareous cow parity was $0.3 \%$ for each and there were no statistically significant association between parity status of the cows and brucellosis seropositivity (Table 1).

The serology result of the apparent study also reveals positive test result recorded in animals managed in semi-intensive $(0.3 \%)$ and extensive production systems $(0.3 \%)$ than in those of intensive systems. A higher seroprevalence of brucellosis was observed on small holder farmers than large scale and medium scale farms. All cases of positive animal were kept at poor hygiene barn. Most of the cows were separated during parturition from the herd even though most respondents have no parturition pen (Table 1).

The results of multivariable Firth's Bias-Reduced Logistic Regression analysis showed the association of predictor variable with bovine brucellosis seropositivity. There was no multicollinearity between variables. Accordingly the stepwise multivariable Firth's Bias-Reduced Logistic Regression analysis results were showed important risk factors for bovine brucellosis seropositivity. Therefore, stage of abortion, retained fetal membrane, source of animal and presence of parturition pen were included in the final model. However, stages of abortion, RFM and source of animal for replacement were significantly associated with brucellosis seropositivity (Table 2).

Thus the reduced model depicted that cows with late stage of abortion, retained fetal membrane, and market purchase herd replacement were $1.283,1.046$ and 1.0638 times more likely to be seropositive to 
Brucella infection than with early stage of abortion, without retained fetal membrane, and own and government source of herd replacement respectively.

Table 2

Multivariable Firth's Bias-Reduced Logistic Regression analysis of risk factors associated with dairy cow brucellosis seropositivity by combined RBPT and CFT

\begin{tabular}{|c|c|c|c|c|}
\hline Variables & No. of cow tested & CFT (\%) & $\mathrm{OR}(95 \% \mathrm{Cl})$ & P-Value \\
\hline \multicolumn{5}{|l|}{ Stage of abortion } \\
\hline Early stage & 339 & 0 & 1 & \\
\hline Late Sage & 13 & $2(0.6)$ & $1.283(1.215-1.3557)$ & $0.000 \star^{\star \star \star}$ \\
\hline \multicolumn{5}{|l|}{ RFM } \\
\hline No & 304 & 0 & 1 & \\
\hline Yes & 48 & $2(0.6)$ & $1.046(1.0187-1.0754)$ & $0.0014^{\star \star}$ \\
\hline \multicolumn{5}{|c|}{ Source of stock replacement } \\
\hline Government & 1 & 0 & 1 & \\
\hline Own source & 198 & $1(0.3)$ & $6.549(30.066-76.357)$ & 0.075 \\
\hline Market Purchase & 16 & $1(0.3)$ & $1.0638(1.026-1.1029)$ & $0.0008^{\star \star \star}$ \\
\hline Both & 52 & 0 & & 0.399 \\
\hline \multicolumn{5}{|c|}{ Presence of parturition pen } \\
\hline Yes & 7 & 0 & 1 & 0.281 \\
\hline No & 260 & $2(0.6)$ & $0.025-0.032$ & \\
\hline
\end{tabular}

Seroprevalence of Brucellosis in Dairy Cattle Owners and Dairy Farm Workers

Owners of dairy cow with a history of recent abortion from twenty two kebeles ( 147 human), government workers from EIAR HARC Holeta and Adda Berga large scales dairy farms (17 human), and farm owners from three medium scale farm (3 human) were sampled for this study. The present result revealed that out of 166 human serum sample tested (109 male serum and 57 female serum), about 7 (4.2\%) (95\% Cl: $0.02046-0.08425$ ) were tested positive by RBPT. Sera screened positive for RBPT were further confirmed with CFT which showed 2 sera were confirmed positive, giving overall seroprevalence of human brucellosis among the blood samples tested was $1.2 \%(95 \% \mathrm{Cl}: 0.003289-0.04278)$ in the study area (Fig. 2).

Association of putative risk factors with human brucellosis seropositivity 
Univariable Firth's Bias-Reduced Logistic Regression analysis for association between human brucellosis and different risk factors using combined RBPT and CFT were carried out. Out of 166 serologically screened serum samples, 2 (1.2\%) farm workers from EIAR Adaberga large scale dairy farm, 3(1.8\%\%) small holder farmers from Burka Harbu and 2(1.2\%) from Goro Kerensa kebele of Holeta Town were positive by RBPT and 2(1.2\%) from Burka Harbu kebele were further confirmed by CFT. The finding also indicated that there was no statistically significant difference between brucellosis seropositivity and human origin $(P>0.05)$ (Table 3$)$. 
Table 3

Univariable Firth's Bias-Reduced Logistic Regression analysis of risk factors associated with human brucellosis seropositivity

\begin{tabular}{|c|c|c|c|c|c|}
\hline \multirow[t]{2}{*}{ Variables } & \multirow{2}{*}{$\begin{array}{l}\text { No. } \\
\text { sampled }\end{array}$} & \multicolumn{2}{|c|}{ No. positive (\%) } & \multirow[t]{2}{*}{ OR(95\%Cl) } & \multirow[t]{2}{*}{ P-Value } \\
\hline & & $\begin{array}{l}\text { RBPT } \\
(\%)\end{array}$ & $\begin{array}{l}\text { CFT } \\
(\%)\end{array}$ & & \\
\hline \multicolumn{6}{|l|}{ Origen/site } \\
\hline HARC Berga farm & 4 & $2(1.2)$ & 0 & 1.0 & \\
\hline HARC Holeta farm & 13 & 0 & 0 & $\begin{array}{l}3.33(1.6771- \\
66.0154)\end{array}$ & 0.603 \\
\hline Holeta Town & 55 & $5(3.01)$ & $2(1.2)$ & $4.21(0.276-61.4554)$ & 0.623 \\
\hline Walmera district & 94 & 0 & 0 & $\begin{array}{l}4.76(0.2433- \\
9.2818)\end{array}$ & 0.191 \\
\hline \multicolumn{6}{|l|}{ Sex } \\
\hline Male & 109 & $4(2.4)$ & $2(1.2)$ & $\begin{array}{l}2.67(2.1291- \\
37.1307)\end{array}$ & 0.486 \\
\hline Female & 57 & $3(1.8)$ & 0 & 1.0 & \\
\hline \multicolumn{6}{|l|}{ Age } \\
\hline$<30$ years & 41 & $1(0.6)$ & 0 & 1 & \\
\hline $31-45$ years & 91 & $6(3.6)$ & $2(1.2)$ & $\begin{array}{l}1.91(0.1498- \\
2.6617)\end{array}$ & 0.658 \\
\hline $46-60$ years & 30 & 0 & 0 & $\begin{array}{l}0.66(0.0035- \\
0.1238)\end{array}$ & 8.38 \\
\hline$>60$ years & 4 & 0 & 0 & $\begin{array}{l}6.99(0.0357- \\
1.3771)\end{array}$ & 0.373 \\
\hline \multicolumn{6}{|l|}{ Educational status } \\
\hline College & 18 & 0 & 0 & 1.0 & \\
\hline Not read and write & 34 & $1(0.6)$ & $1(0.6)$ & $\begin{array}{l}1.66(0.0839- \\
0.2468)\end{array}$ & 0.752 \\
\hline Non-academic & 4 & $1(0.6)$ & 0 & $\begin{array}{l}4.11(0.0208- \\
8.1315)\end{array}$ & 0.507 \\
\hline Informal & 6 & 0 & & $\begin{array}{l}2.85(0.0146- \\
55.2905)\end{array}$ & 0.616 \\
\hline Primary school & 69 & $4(2.4)$ & $1(0.6)$ & $\begin{array}{l}0.81(0.0414- \\
120.241)\end{array}$ & 0.9004 \\
\hline
\end{tabular}




\begin{tabular}{|c|c|c|c|c|c|}
\hline \multirow[t]{2}{*}{ Variables } & \multirow{2}{*}{$\begin{array}{l}\text { No. } \\
\text { sampled }\end{array}$} & \multicolumn{2}{|c|}{ No. positive (\%) } & \multirow[t]{2}{*}{$\mathrm{OR}(95 \% \mathrm{Cl})$} & \multirow[t]{2}{*}{ P-Value } \\
\hline & & $\begin{array}{l}\text { RBPT } \\
(\%)\end{array}$ & $\begin{array}{l}\text { CFT } \\
(\%)\end{array}$ & & \\
\hline Secondary school & 28 & $1(0.6)$ & 0 & $\begin{array}{l}0.65(0.0034- \\
1.2233)\end{array}$ & 0.831 \\
\hline University & 7 & 0 & 0 & $\begin{array}{l}2.467(0.0127- \\
47.664)\end{array}$ & 0.663 \\
\hline \multicolumn{6}{|l|}{ Human housing } \\
\hline $\begin{array}{l}\text { Common housing with dairy } \\
\text { animals }\end{array}$ & 14 & $3(2)$ & $2(1.2)$ & $1.8(0.013-0.2426)$ & $0.0022^{* *}$ \\
\hline Separate housing & 135 & $2(1.3)$ & 0 & 1.0 & \\
\hline \multicolumn{6}{|l|}{ Contact with aborted fetus } \\
\hline Yes & 89 & $7(4.2)$ & $2(1.2)$ & $\begin{array}{l}21.19(1.6708- \\
2.9513)\end{array}$ & $0.017^{\star}$ \\
\hline No & 77 & 0 & 0 & 1.0 & \\
\hline \multicolumn{6}{|c|}{ Way of contact with aborted material } \\
\hline Bare hand & 89 & $7(4.2)$ & $2(1.2)$ & 1.0 & \\
\hline Wear glove & 20 & 0 & 0 & $\begin{array}{l}0.84(6.0283- \\
10.9012)\end{array}$ & 0.912 \\
\hline Using plastic & 55 & 0 & 0 & $\begin{array}{l}0.31(0.02204- \\
3.85402)\end{array}$ & 0.394 \\
\hline With other material & 2 & 0 & 0 & $\begin{array}{l}6.92(0.0455- \\
12.58103)\end{array}$ & 0.331 \\
\hline \multicolumn{6}{|c|}{ Washing hands after handling aborted materials } \\
\hline Yes & 147 & $6(3.4)$ & $2(1.2)$ & 1.0 & 0.609 \\
\hline No & 19 & $1(0.6)$ & 0 & $\begin{array}{l}0.67(0.0519- \\
93.7542)\end{array}$ & 0.81 \\
\hline \multicolumn{6}{|l|}{ Drinking row milk } \\
\hline Yes & 137 & $7(4.2)$ & $2(1.2)$ & $\begin{array}{l}24.99(1.9644- \\
3.4857)\end{array}$ & $0.012^{*}$ \\
\hline No & 29 & 0 & 0 & & \\
\hline \multicolumn{6}{|c|}{ Drinking habit of milk from aborted cow } \\
\hline Boiling & 47 & $1(0.6)$ & 0 & 1.0 & \\
\hline
\end{tabular}




\begin{tabular}{|c|c|c|c|c|c|}
\hline \multirow[t]{2}{*}{ Variables } & \multirow{2}{*}{$\begin{array}{l}\text { No. } \\
\text { sampled }\end{array}$} & \multicolumn{2}{|c|}{ No. positive (\%) } & \multirow[t]{2}{*}{$\mathrm{OR}(95 \% \mathrm{Cl})$} & \multirow[t]{2}{*}{ P-Value } \\
\hline & & $\begin{array}{l}\text { RBPT } \\
(\%)\end{array}$ & $\begin{array}{l}\text { CFT } \\
(\%)\end{array}$ & & \\
\hline Without boiling & 43 & $6(3.5)$ & $2(1.2)$ & $\begin{array}{l}5.72(44.893- \\
79.8198)\end{array}$ & $0.019 *$ \\
\hline Not drinking & 76 & 0 & 0 & $\begin{array}{l}0.62(3.3394- \\
11.5445)\end{array}$ & 0.813 \\
\hline \multicolumn{6}{|c|}{ Drinking habit of milk from RFM cow } \\
\hline Boiling & 75 & 0 & 0 & 1.0 & \\
\hline Without boiling & 91 & $7(4.2)$ & $2(1.2)$ & $\begin{array}{l}4.2178(3.3643- \\
5.8527)\end{array}$ & $0.029 *$ \\
\hline \multicolumn{6}{|c|}{ History of abortion } \\
\hline Yes & 9 & $1(0.6)$ & 0 & $3.27(0.023-44.2266)$ & 0.51 \\
\hline No & 48 & $6(3.6)$ & $2(1.2)$ & 1.0 & \\
\hline \multicolumn{6}{|l|}{ History of sterility } \\
\hline Yes & 1 & 0 & 0 & $\begin{array}{l}21.80(0.1359- \\
5.4571)\end{array}$ & 0.167 \\
\hline No & 108 & $7(4.2)$ & $2(1.2)$ & 1.0 & \\
\hline \multicolumn{6}{|c|}{ History of chronic headache } \\
\hline Yes & 66 & $6(3.6)$ & $2(1.2)$ & $\begin{array}{l}7.79(6.2095- \\
10.8132)\end{array}$ & 0.117 \\
\hline No & 100 & $1(0.6)$ & 0 & 1.0 & \\
\hline \multicolumn{6}{|c|}{ History of knee pain } \\
\hline Yes & 68 & $4(2.4)$ & $2(1.2)$ & $\begin{array}{l}7.59(6.0545- \\
10.5418)\end{array}$ & 0.123 \\
\hline No & 98 & $3(1.8)$ & 0 & 1.0 & \\
\hline \multicolumn{6}{|c|}{ History of testicular swelling } \\
\hline Yes & 5 & $2(1.2)$ & $2(1.2)$ & $\begin{array}{l}230.71(15.332- \\
34.33)\end{array}$ & $0.000 * * \star$ \\
\hline No & 104 & $5(3)$ & 0 & 1.0 & \\
\hline
\end{tabular}

Demographic factors (age, sex and educational status), factors related with human animal contacts (human housing, contact with aborted fetus, way of contact with aborted material, drinking row milk, drinking raw milk from aborted cow, and drinking raw milk from cow with RFM), and symptoms from disease events experienced during the previous month (history of abortion, history of sterility, history of 
chronic headache, history of knee pain and history of Orchitis) were compared to the sero-status of participants.

The Risk factor analysis showed that there was statistically significant associations between human brucellosis and human housed with dairy animals $(O R=1.8, p=0.002)$, contact with aborted fetus (OR= $21.19, p=0.017)$, drinking row milk $(O R=24.99, p=0.012)$, drinking raw milk from aborted animals $(O R=$ $5.72, p=0.019)$, drinking raw milk from cow with $R F M(O R=4.217, p=0.029)$ and Orchitis $(O R=230.71, p$ $=0.000)$ (Table 3).

There were no statistically significant difference between males and females in seropositivity $(P>0.05)$. Relatively high brucellosis seropositivity was observed in male respondents than in female. The difference in seropositivity among the different age groups was not statistically significant. However, the highest proportion of seropositive individuals was observed at age group between 31-45 years. In other way high seroprevalence were observed in respondents who are not educated or low grade educational level, even though there is no statistically significant association between educational status and human brucellosis (Table 3 ).

The most common symptoms of human brucellosis mentioned by respondents were abortion $9(5.42 \%)$, sterility $1(0.6 \%)$, chronic headache 66(39.8\%), knee pain 68(40.9\%), and testicular swelling 5(3.01\%). Statistically significant association was observed in respondents with a history of testicular swelling (Table 3).

The results of multivariable Firth's Bias-Reduced Logistic Regression analysis showed the association of predictor variable with human brucellosis seropositivity. Generally there was no multicollinearity between variables. Accordingly the stepwise multivariable Firth's Bias-Reduced Logistic Regression analysis results were showed important risk factors for brucellosis seropositivity. Therefore, human housing, contact with aborted fetus, drinking raw milk and history of Orchitis were included in the final model. Thus the analysis depicted that human who had common housing with dairy animals, contact with aborted fetus with bare hand, drinking row milk, and had history of Orchitis were 1.947, 1.022, 1.019, and 1.919 times more likely to be seropositive to Brucella infection than human who had separate housing, use protective materials when contact with aborted fetus, boiling before drinking raw milk and did not had history of Orchitis respectively (Table 4).

Seroprevalence, recorded for human housed with dairy animals revealed a statistically significant variation with odds of being seropositive by 1.497 times more likely to be infected with Brucella organisms than human who had separate housing with animals. Similarly, contact with aborted fetus with bare hand and drinking raw milk without boiling were found to be statistically significantly associated with seropositivity. Seropositivity to human brucellosis was significantly higher in human those make a contact with aborted fetus with bare hand with 1.022 times more likely to be seropositive than humans those make a contact using protective materials. 
Table 4

Multivariable Firth's Bias-Reduced Logistic Regression analysis of risk factors associated with human brucellosis seropositivity

\begin{tabular}{|c|c|c|c|c|}
\hline Variables & No. Sampled & CFT (\%) & OR (95\% Cl) & P-Value \\
\hline \multicolumn{5}{|l|}{ Human housing } \\
\hline With dairy animals & 14 & 0 & 1 & \\
\hline Separate housing & 135 & $2(1.2)$ & $1.947(0.912-0.983)$ & $0.0049^{\star \star}$ \\
\hline \multicolumn{5}{|c|}{ Contact with aborted fetus } \\
\hline No & 77 & 0 & 1 & \\
\hline Yes & 89 & $2(1.2)$ & $1.022(0.989-1.057)$ & $0.012^{*}$ \\
\hline \multicolumn{5}{|l|}{ Drinking row milk } \\
\hline No & 29 & 0 & & \\
\hline Yes & 137 & $2(1.2)$ & $1.019(0.98491 .055)$ & $0.046^{*}$ \\
\hline \multicolumn{5}{|l|}{ History of Orchitis } \\
\hline No & 161 & 0 & & \\
\hline Yes & 5 & $2(1.2)$ & $1.919(1.775-2.076)$ & $0.000 * * *$ \\
\hline
\end{tabular}

Questionnaire Surveys

Demographic characteristics of the respondents

A total of 284 participants were interviewed ( 213 male and 71 female) to assess their knowledge, attitude and practices towards brucellosis. From those respondents $2(0.7 \%)$ were large scale farm managers, 11 (3.9\%) medium scale farm owners, 254 (89.4\%) small holder farmers and 17(5.9\%) government farm employees. About $3.9 \%$ of respondents were university graduate, $11.7 \%$ collage graduate, $16.5 \%$ secondary education, $29.9 \%$ primary education, $20.4 \%$ not read and write and $13.7 \%$ informal. Majority of respondent population of the participants $(49.3 \%)$ were in $35-45$ age groups. Also $242(85.2 \%)$ of the participants were married and $42(14.8 \%)$ were single (Table 5). 
Table 5

Demographic characteristics of respondents

\begin{tabular}{|lll|}
\hline Demographic variables & No. Respondents & Percentage (\%) \\
\hline Gender & & \\
\hline Male & 213 & 75 \\
\hline Female & 71 & 25 \\
\hline Age categories & & \\
\hline Young & 57 & 20.1 \\
\hline Middle age & 140 & 49.3 \\
\hline Adult & 71 & 25 \\
\hline Old & 16 & 5.6 \\
\hline Marital status & & \\
\hline Married & 242 & 85.2 \\
\hline Single & 42 & 14.8 \\
\hline Educational status & & 3.9 \\
\hline Not read and write & 58 & 0.7 \\
\hline Informal & 39 & 20.4 \\
\hline Non academic & 11 & 13.7 \\
\hline Primary school & 85 & 3.9 \\
\hline Secondary school & 47 & 29.9 \\
\hline College & 33 & 16.5 \\
\hline University & 254 & \\
\hline Animal ownership status & & \\
\hline Farm employees & 11 & \\
\hline Small holder animal owners & & \\
\hline Medium scale farm owners & 11 & \\
\hline Large scale farm owners & 2 & \\
\hline
\end{tabular}

Farm characteristics of different scale farms 
Management system of both two large scale farms have semi intensive, eight of medium scale farms have intensive and 4 of them have semi intensive management system while most small holder (164) farmers have extensive management system. It was also found that, $57(34.8 \%)$ of sampled cows from large scale were using Al breed system, while 107(97.3\%) of small holder farmers were dependent on natural mating and also $76(97.4 \%)$ of small holder farmers were using both Al and natural mating (Table 6).

More than half of large scale, medium scale and small holder farmers were dependent on own sources for replacement stock. The practices of provision of separate parturition pens, separation of cows during parturition, and cleaning and disinfection of contaminated areas was done in a relatively better in the intensive management system. In addition, 43 small holder farmers encounter a problem of repeat breeding (Table 6). 
Table 6

Farm characteristics of different scale farms

\begin{tabular}{|c|c|c|c|}
\hline \multirow[t]{2}{*}{ Variables } & \multicolumn{3}{|c|}{ Proportion of Respondents } \\
\hline & Large scale farm (\%) & Medium scale farm (\%) & Small holder farmer (\%) \\
\hline \multicolumn{4}{|l|}{ Type of farming } \\
\hline Extensive & 0 & 0 & $164(100)$ \\
\hline Intensive & 0 & $8(25)$ & $24(75)$ \\
\hline Semi intensive & $2(2.8)$ & $3(4.2)$ & 66(93) \\
\hline \multicolumn{4}{|c|}{ Source of stock replacement } \\
\hline Own farm raised & $55(19.4)$ & $29(10.2)$ & $200(70)$ \\
\hline Market purchased & $3(6.1)$ & $10(20.4)$ & $36(73.5)$ \\
\hline Government gift & 0 & $1(5.3)$ & 18(94.7) \\
\hline \multicolumn{4}{|l|}{ Service type } \\
\hline Al & $56(34.8)$ & $33(22)$ & $48(43.3)$ \\
\hline Natural mating & $1(0.9)$ & $2(1.8)$ & 107(97.3) \\
\hline Both & 0 & $2(1.6)$ & $76(97.4)$ \\
\hline \multicolumn{4}{|c|}{ Having parturition pen } \\
\hline No & 0 & $8(3.1)$ & $251(96.9)$ \\
\hline Yes & $2(28.6)$ & $2(28.6)$ & $3(42.9)$ \\
\hline \multicolumn{4}{|c|}{ Cleaning parturition area after birth } \\
\hline Yes & $2(0.75)$ & $2(0.75)$ & $4(1.49)$ \\
\hline No & 0 & $9(3.37)$ & $250(93.63)$ \\
\hline \multicolumn{4}{|l|}{ Hygiene of barn } \\
\hline Good & $30(29.7)$ & 12(11.9) & $59(59.4)$ \\
\hline Medium & $28(20)$ & $23(16.4)$ & $89(63.6)$ \\
\hline Poor & 0 & $5(4.3)$ & 106(95.5) \\
\hline \multicolumn{4}{|l|}{ Repeat breeding } \\
\hline No & $50(16.8)$ & $37(12.4)$ & 211(70.8) \\
\hline Yes & $8(14.8)$ & $3(5.6)$ & $43(79.6)$ \\
\hline
\end{tabular}


Knowledge, attitude and practices regarding brucellosis

In current study the majority of respondents, 265(93.3\%) had no information about brucellosis while $19(6.7 \%)$ of respondents had information and knowledge about brucellosis in human and animal. The analysis result showed that most of the dairy animal owners, $173(60.9 \%)$ consumed raw milk and $111(39.1 \%)$ had not reported to consume raw milk. Respondents also reported that milk from aborted cows were not consumed by $128(45.1 \%)$, consumed without boiling by $80(28.2 \%)$ of respondents and $76(26.8 \%)$ of respondents were boiled before consuming. Majority of the respondents, $250(88 \%)$ mentioned that they had poor knowledge on zoonotic diseases and its transmission mechanism via dairy animals and animal products. Only 27(9.5\%) of respondents had knowledge about zoonotic diseases transmitted through raw milk consumption.

In the current study $168(59.2 \%)$ of respondents handled aborted fetus without using personal protective equipment, while $80(28.2 \%)$ used plastic, $25(8.8 \%)$ used glove and the remaining $11(3.9 \%)$ had removed aborted fetus using other materials. It was also found that the majority of the farm respondents, 225 (79.2 \%) were removing fetal and aborted materials on the open field while some others were burial after birth or abortion, and limited respondents feed to dogs especially those of small holder farmers and medium herd size farms owners (Table 7). 
Table 7

Knowledge, Attitudes and Practices (KAP) of respondents regarding brucellosis

\section{Variables}

No.

Respondents

Frequency

(\%)

Drinking raw milk

No

111

39.1

Yes

173

60.9

Milk from aborted cow

Boiling before drinking

76

26.8

Drink without boiling

80

28.2

Not drink

128

45.1

Milk from cow with RFM

Boiling before drinking

118

41.5

Drink without boiling

166

58.5

Knowledge on Brucellosis

No

265

93.3

Yes

19

6.7

Knowledge on zoonotic diseases transmitted by handling of infected animal and animal products

No

250

88

Yes

34

12

Knowledge on zoonotic diseases due to raw milk consumption

No

257

90

Yes

27

9.5

Contact with aborted fetus

No

116

40.8

Yes

168

59.2

Way of contact with aborted fetus

Bare hand

168

59.2

Wear glove

25

8.8

Wear plastic

80

28.2

Page 19/41 


\begin{tabular}{|c|c|c|}
\hline Variables & $\begin{array}{l}\text { No. } \\
\text { Respondents }\end{array}$ & $\begin{array}{l}\text { Frequency } \\
(\%)\end{array}$ \\
\hline With other material & 11 & 3.9 \\
\hline \multicolumn{3}{|c|}{ Method of disposing aborted fetus } \\
\hline Feeding for dog & 12 & 4.2 \\
\hline Burial & 32 & 11.3 \\
\hline Incineration borrow & 15 & 5.3 \\
\hline Remove on open field & 225 & 79.2 \\
\hline \multicolumn{3}{|c|}{ Hand washing after contact with aborted fetus } \\
\hline No & 259 & 91.2 \\
\hline Yes & 25 & 8.8 \\
\hline
\end{tabular}

Occupational risks among farm works and dairy cattle owners

In study area about 95 (37.4\%) of small holder farmers had common housing with dairy animals. The result showed that only $8(42.1 \%), 1(9.1 \%)$ and $15(5.9 \%)$ of respondents from large scale, medium scale farms and small holder animal owners were aware of brucellosis respectively. Up to 11(57.9\%), 10(90.9\%) and $239(94.1 \%)$ of the respondents from large scale and medium scale farms, and small holder animal owners were reported that they had poor knowledge about brucellosis respectively. There was statistically significant variation between the indicated variables $(P<0.05)$ as shown in $($ Table 8$)$. 
Table 8

Occupational risks and awareness among farm works and owners about brucellosis

\begin{tabular}{|c|c|c|c|c|c|}
\hline \multirow[t]{2}{*}{ Variables } & \multicolumn{3}{|c|}{ Proportion of Respondents } & \multirow{2}{*}{$\begin{array}{l}\mathrm{X}^{2}- \\
\text { value }\end{array}$} & \multirow{2}{*}{$\begin{array}{l}\mathrm{P}- \\
\text { value }\end{array}$} \\
\hline & $\begin{array}{l}\text { Large scale } \\
\text { farm (\%) }\end{array}$ & $\begin{array}{l}\text { Medium scale } \\
\text { farm (\%) }\end{array}$ & $\begin{array}{l}\text { Small holder } \\
\text { farmer (\%) }\end{array}$ & & \\
\hline \multicolumn{6}{|l|}{ Human housing } \\
\hline $\begin{array}{l}\text { Common with dairy } \\
\text { animals }\end{array}$ & 0 & 0 & $95(37.4)$ & 7.548 & 0.016 \\
\hline Separate & $2(100)$ & 11(100) & $159(62.6)$ & & \\
\hline \multicolumn{6}{|c|}{ Awareness about zoonotic brucellosis } \\
\hline No & 11(57.9) & 10(90.9) & 239(94.1) & 29.949 & 0.000 \\
\hline Yes & $8(42.1)$ & $1(9.1)$ & $15(5.9)$ & & \\
\hline \multicolumn{6}{|c|}{ Awareness about zoonotic diseases transmission through drinking raw milk } \\
\hline No & $8(7.2)$ & $10(9)$ & 93(83.3) & 13.333 & 0.001 \\
\hline Yes & $11(6.4)$ & $1(0.6)$ & 161(93.1) & & \\
\hline \multicolumn{6}{|c|}{ Contact with aborted fetus } \\
\hline No & 17(14.7) & $10(8.6)$ & $89(76.7)$ & 33.55 & 0.000 \\
\hline Yes & $2(1.2)$ & $1(0.6)$ & $165(98.2)$ & & \\
\hline \multicolumn{6}{|l|}{ Contact with RFM } \\
\hline No & 19(9.6) & $11(5.2)$ & $180(87.5)$ & 11.82 & 0.003 \\
\hline Yes & 0 & 0 & $74(100)$ & & \\
\hline
\end{tabular}

\section{Discussion}

The present study revealed that the overall seroprevalence of Brucella antibodies determined with RBPT and CFT in Holeta Town, Wolmera and Adea Berga EIAR dairy farm, Ethiopia were $1.2 \%$ and $0.6 \%$ in animals with history of recent abortion. Since CFT is recommended as confirmatory test for brucellosis with high specificity [12], the overall seroprevalence of bovine brucellosis in the study area was $0.6 \%$.

The seroprevalence in this study was slightly higher than the finding of [8] who reported an overall prevalence of $0.06 \%$ in Addis Ababa area. This variation in seroprevalence might be seen due to the difference in the study animal management system. Most of reactive animals in my study were from small holder farmers kept under extensive management system. The dependency of most of the farmers on outside sources for stock replacement could be one possible way of introduction of the disease into 
unaffected herds. This could also be due to differences between the study areas regarding conditions that could facilitate the rate of transmission of the disease [16].

The finding of my study was in close agreement with the findings of [17] (0.69\%); [18] (0.77 \%); [19] $(0.9 \%) ;[20](1.0 \%)$; from Ethiopia and [21] (1.0\%) from Kenya. On the other hand, there were reports with a relatively higher seroprevalence of bovine brucellosis in other parts of the country; [5] (3.19\%); [6] (3.1\%); [35] (11.0\%); [22] (2.9\%); [23] (1.38\%); [24] (6.1\%); [25] (3.5\%); [26] (1.9\%); [27] (4.3\%); [28] (1.4\%). Similarly, relatively higher seroprevalence were reported in other African countries by other authors: $8.5 \%$ [29] from Eritrea, 24.5\% [30] from Sudan; 24.0\% [31] from Zimbabwe; 5.5\% [32] from Nigeria were some of the reports.

The difference observed in prevalence could be due to variation in production systems and animal management. Most of the previous higher prevalence studies which reported by different authors were in extensively managed herds, where cattle from several owners mingle at grazing or watering points. According to the result in my study all of the confirmed case was from extensively managed small holder dairy animal owners. Hence, the reasons for the low prevalence of bovine brucellosis in this study areas could possibly be explained by better hygienic practices, separation of cows during parturition, cleaning and disinfection activities, culling of infected animals and depending on own herds for replacing stock in the two large scale and eleven medium scale farms, and the prevailing management differences between the intensive, semi-intensive and extensive production systems. This is also reflected the relatively good hygienic status of the farms and practices in disposing aborted materials to ward off contact with animals.

In addition to estimation of seroprevalence, this study was also carried out to assess the risk factors associated with disease occurrence. The previous history of abortion stage hah statistically significant association with seropositivity of bovine brucellosis. This was in agreement with previous reports of [28]. This could be explained by the presence of higher seropositivity in cows in the last trimester which may be due to the preferential localization of Brucella in the uterus, in which allantoic fluid factor, erythritol stimulate the growth of Brucella and elevate in the placenta and fetal fluid from about the 5th month of gestation [12,33].

In addition to this there was a highly significant association between cows with history of retained fetal membrane and seropositivity of brucellosis in present study. Retention of the placenta and inflammation of the wall of the uterus (metritis) are common sequelae to abortion due to brucellosis, [34] reported that Brucella infected cows were expected to abort 3 to 4 times more than unexposed cows. This could also be explained by the fact that retained fetal membrane is typical outcomes of brucellosis. Other studies have also shown a significant association between seropositivity and retained fetal membrane $[5,6,10$, $18,20]$.

There were statistically significant differences in seroprevalence of brucellosis seropositivity and breeding methods. In the present study area most farms used Artificial insemination (38.9\%) than bull $(22.7 \%)$ for breeding purpose. There was higher seroprevalence rate in bull service, whereas no 
seropositive record in Al mating method. The sources of replacement stock $(p=0.021)$ were shown to significantly affect the prevalence of bovine brucellosis in study areas. Those animals purchased from other area were relatively suffer of brucellosis than cattle grown and replaced the stock.

There was no statistically significant difference $(P>0.005)$ between seroprevalence of brucellosis and dairy cow origins. The finding was in line with report by [34] that, there was no statistically significant variation in seroprevalence of brucellosis among different origin. Even though, there was no statistically significant association, high prevalence of brucellosis was observed in dairy cows of Holeta Town Burka Harbu kebele $(0.6 \%)$ than all other kebeles and farms. The reasons for the variations in brucellosis seroprevalence among the study areas might be related to the difference in management practice performed in the three study sites. In addition, different studies revealed that the seroprevalence of brucellosis is affected by different agro climate conditions, which determine survival of Brucella organisms [12].

According to the result of my study Brucella infection did not show significant variation between breeds. The present finding agrees with the previous reports of $[26,28,35]$ who reported seropositivity of Brucella infection was independent of the breeds. The variation in number of animals sampled per breed group might be accountable for the absence of significant variation of Brucella infection between the breeds .On the other hand in my study site cross breed were increasing and the farmers give high care for cross breed cow than local breeds.

According to the present study, there was no statistically significant different among age groups to Brucella seropositivity. All positive cows (0.6\%) were found among adult age group whereas no Brucella seropositivity was observed in young and old age group of dairy cattle in the study sites. Similar findings were also reported by $[22,65]$ where age was not significantly associated with Brucella seropositivity.

The higher seroprevalence of brucellosis among adult cows may be related to the higher number in adult cow included in the study. In addition, may related to their advanced age as the organism may remain latent or chronic for an unspecified period before manifesting as clinical disease. The other justification also possible as age is one of the intrinsic factors which influence the susceptibility to Brucella infection. Brucellosis appears to be more associated with sexual maturity [16]. It is essentially a disease of sexually mature animals and susceptibility increases with sexual maturity and pregnancy due to the influence of sex hormones and placenta erythritol on the pathogenesis of brucellosis [12]. On the other hand, younger animals tend to be more resistant to infection and frequently clear infections, although latent infections could occur (36).

The parity status was not found to be a significant determinant of seroprevalence. In present study, 1 of the seropositive cow was in their pluripareous parity status whereas the other 1 from primipareous. Furthermore, of parity status $83.8 \%(n=295)$ of cows were pluripareous whereas about $12.2 \%(n=57)$ were primipareous. Hence, the present finding is in line with reports of, $[18,20,26,28]$ where parity status were not significantly associated with Brucella seropositivity. The reason of the similarity of Brucella infection among the parity could be due to the difference in the number of animals included for the study. 
The finding of this study revealed that relatively higher seroprevalence of brucellosis was observed in extensive $(0.3 \%)$ and semi-intensive $(0.3 \%)$ management system than intensive management systems though the finding was not statistically significant. A relatively higher seroprevalence observed in this study, in the extensive and semi-intensive management system could be partly explained by the fact that contact between animals increases in communal grazing practices which was the predominant feeding system in the extensive and semi-intensive type of management. In such circumstances, cattle of unknown disease status might mix and often grazed together and resulted in spreading and transmission of disease among herds. About $90.9 \%$ of the farms in the study area shared the communal grazing system. It has also been indicated that free grazing which allows unrestricted contact between animals may have contribution to the spread of brucellosis in extensive management system [37].

The lower prevalence recorded in the intensive management system in the study area could be due to the better hygienic practices in the intensive management system which was expressed by the relatively better proportion of farm owners having separate parturition pens, separating cows during parturition, performing cleaning and disinfection duties, depending on own herd for replacing stock and having better knowledge about the disease. Brucellosis has been labeled to be a disease of poor hygienic condition that would exposure animals to aborted fetus, placentas, vaginal discharges or newborn calves from infected cows. Likewise, the use of maternity pens at calving is proved to be associated with a decrease in prevalence of infection, presumably due to decreasing the exposure of infected and susceptible animals [16].

Farm hygiene was observed based on manure disposal, drainage, and physical appearance of the animal and ventilation status of the farms. Accordingly, most of the farms' hygiene was fair, and some were good while the other some were poor. Even though this risk factor had no any statistical significant association with occurrence of brucellosis the high seroprevalence was recorded in poor hygienic barns $(0.6 \%)$. Though, keeping good hygiene at dairy farm [39] are considered as a protective factor for brucellosis, unhygienic practices were identified as factors that will facilitate the spread of Brucella infections [40].

Serum samples from 149 recently aborted dairy cow owners and 17 government farm employees were examined for the presence of brucellosis. Of the total examined human, seroprevalence of brucellosis using RBPT and CFT was found to be $4.2 \%$ and $1.2 \%$, respectively. Since CFT is recommended as confirmatory test for brucellosis with high specificity [16], the overall seroprevalence of human brucellosis in the study area was $1.2 \%$.

It is not surprising to get people infected with brucellosis in an area where there are infected animals since the prevalence of brucellosis in human is largely influenced by the prevalence of disease among domestic animals around [29]. The findings of this study are relevant for the country towards the development of a national brucellosis control program by the medical and veterinary sectors. Our study provides evidence that brucellosis is one of the public health problems among the rural and urban population of Ethiopia. 
In Ethiopia, very few studies have been conducted to determine seroprevalence of human brucellosis. The similar studies by [24] (1.2\%) in Western Tigray was reported. Compared to the present study, however, the relatively higher seroprevalence of brucellosis observed by [7] (16.5\%); [24] (2.2\%); [42] (3.8\%); [43] (2.2\%); [52] (4.8\%) might be attributed to the large sample size involved and/or the different confirmatory tests used by the two studies, CFT versus 2-mercaptoethanol test (MET). The lower prevalence in our study could also be due the fact that the number of livestock, level of contact with animals and frequency of consumption of dairy products is low as compared to the mentioned study.

Our findings were lower compared to studies in Uganda that recorded a seroprevalence of $5.8 \%$ in Mbarara; $9 \%$ in Kampala as reported by [44]; a seroprevalence of $11 \%$ carried out in the Southwest Uganda by [45]. However, in these studies, the study populations were high risk livestock keeping populations with a high dairy industry and with a high consumption of milk as well as locally made milk products. This might be correlated exposure of abattoir worker for brucellosis infected animal and animal discharges. Brucellosis is an occupational disease, occurring most often in veterinarians, farmers, stock inspectors, abattoir workers, laboratory personnel, butchers [47].

In present study, strong statistically significant association was seen between human brucellosis seroprevalence and human housing, contact with aborted fetus, drinking row milk, drinking raw milk from aborted animals, drinking raw milk from cow with RFM and history of testicular swelling.

Statistically significant association seen between human Brucella seroprevalence and human housing and contact with aborted fetus was agreed with reports of [7] from Ethiopia. This may be due more cases of human brucellosis occurred in rural areas where most of the people are farmers or in close contact with animals. The other possible explanation could be given from this finding is that both farmers, animal health personnel and farm government employees could be infected while helping infected cows during parturition either through abrasions or the conjunctiva, acquire infections by handling tissues containing Brucella organisms, and also can contracts brucellosis either by handling infected animals or by living with infected animal in similar house.

In the present study, strong association was observed between seropostivity and handling of parturient materials, drinking row milk, drinking raw milk from aborted animals and drinking raw milk from cow with RFM which is in agreement with other studies by $[48,49]$. The possible reason for this may be in our study area most of participants were drink raw milk including raw milk from aborted and retained fetal membrane cow as it was assessed with interview question. The primary method of transmission of Brucella is through raw milk and contact with aborted materials.

The clinical manifestations pertaining to human brucellosis found in this study was similar to previous findings reported by $[7,48,50]$. Apart from general clinical manifestations, participants with a history of testicular swelling had a statistically significant association with Brucella seroprevalence. This might be due the fact that the primary manifestation of brucellosis in man is chronic head ache at early stage and swelling of testicle due to Orchitis. 
There was no statistically significant association between sexes even though high prevalence was seen in male. This finding was in agreement with [50]. All positive sera were from male participants. This may reflect cultural and social behavior patterns whereby the males are actively involved in caring for domestic animals in central high land areas. In this study, higher proportion of seropostivity was observed in age category of 31-45 years age, although the different age categories did not differ significantly. This finding was agreed with the finding of [50,52]. This difference might have been associated with the fact that in the study area age category that were between 31-45 years of age were responsible to handle aborted animals, milking of cows, and continuous contact with animals.

A total of 267 cattle owners and 17 government farm workers were interviewed to assess their awareness levels regarding animal management, brucellosis and occupational risks using structured interview question. Knowledge of diseases is a crucial step in the development of prevention and control measures [53]. Despite huge efforts of the government and non-government institutions to improve animal production in the areas, general knowledge of brucellosis among the farmers was still poor. The educational status attained by majority of the respondents was low which falls between read and write and lower grades. In addition to this, barn hygiene, proper disposal of aborted materials and the use of a separate parturition pen were not well cooperated especially in small holder farmers. These could have led high risks of transmitting the disease within and between the herds and human. This is in agreement with previous studies of $[20,25,54]$. Likewise, mixing of different animal species has its own economic importance by increasing the chances of transmission of brucellosis to the cattle.

Concerning knowledge of brucellosis and other zoonotic diseases, interview question based data were collected. The overall awareness level of brucellosis and other zoonotic diseases among small holder farmers, medium scale farm owners and government farm employees were found to be relatively low. In addition, most of them were not wear protective gloves or other material while handling aborted animals and aborted material. Similar finding was also reported by [55]. This might be attributed to their educational status, since most of the farmers were could not read and write or primary education background. Additionally, it could also be due to a lack of awareness creation program about zoonotic diseases. Generally, a lack of sufficient knowledge of brucellosis and other zoonotic diseases, unprotected working conditions, regular exposure from aerosol and contact through cuts and abrasion to infected materials such as aborted materials, carcasses, viscera, organs, blood and urine are considered as fertile grounds for exposure and transmission of the diseases to humans. In this regard, very little has been done by way of awareness creation of brucellosis.

The result of knowledge assessment showed that brucellosis was not well known by the general community in the present study area, since around $93.3 \%$ of the study respondents had not information about brucellosis. This is similar to findings of previous studies done in Kenya, $80 \%$ of respondents were no knew of the existence of brucellosis whereas in Tajikistan 85\% of the respondents had never heard of brucellosis [56]. 
Most of the respondents from small holder dairy farms relatively did not understand the methods of zoonotic disease transmission including brucellosis. Farmer's lack of awareness about brucellosis, improper handling of aborted materials and the habit of consuming raw milk, among other factors, might contribute to further spread of brucellosis in their livestock and expose the community to a public health hazard [25]. This low awareness is a limiting factor if control strategies are to be implemented. Lack of knowledge on the causative agent, mode of transmission and preventative measures against brucellosis can be detrimental. It is therefore important to establish an educational campaign in the study areas to enlighten the communities on the disease, risk factors as well as control strategies particularly in both livestock and humans.

Based on the questionnaire survey, most of the respondents were handiling abortion and placental retention without using personal protectives (59.2\%); even though using personal protectives are the most known measures against zoonotic brucellosis [12]. These factors combined with the poor hand cleaning practice after contact with aborted materials (91.2\%) by the owners could pose a great risk of the spread of the disease to unaffected animals [41]. In addition, most of the respondents in this study did not bury afterbirth (aborted fetus, still birth and retained fetal membrane) rather they left them on open field (79.2\%).

Studies also assessed the occupational risks that, the majority of the participants in both types of farming systems have the habit of drinking raw milk, contact with aborted fetus and retained fetal membrane. This might be attributed to the culture and tradition of consuming raw milk and milk product and also the lack of knowledge on zoonotic disease via milk and aborted materials. The seroprevalence study research conducted in high risk group such as farmers (livestock owners), veterinary professionals, meat inspectors and artificial insemination technicians in Addis Ababa [52]; [57] in Amhara Regional State found a seroprevalence of $5.30 \%$, and $4.8 \%$ by screening sera from 238 , and 336 individuals respectively.

\section{Conclusion And Recommendations}

The present study revealed that the overall seroprevalence of bovine brucellosis with recent abortion history and human brucellosis from animal owners and farm workers were 0.6 and $1.2 \%$ in Holeta towns, Wolmera District and HARC Adea Berga dairy farm West Shoa, Oromia Region Ethiopia. The finding of positive serological reactors did not only suggest the presence of the disease in the cattle population in the areas, but also indicated the presence of foci of infection that could serve as sources of infection for the spread of the disease into unaffected animals and humans. In this finding stage of abortion, retained fetal membrane, source of stock replacement, and breeding methods were statistically significant risk factors associated with dairy animal brucellosis seropositivity. On the other hand human housing, contact with aborted fetus and RFM, drinking row milk, drinking raw milk from aborted animals and drinking raw milk from cows with RFM were statistically important risk factors associated with human brucellosis seropositivity. This study also provided important information on knowledge, attitude and practice of livestock owners and occupational workers about brucellosis that result in significant zoonotic 
importance of using raw milk for human consumption. This emphasizes impact of brucellosis in animals, public health and the need to control and prevent brucellosis in the study areas.

Based on the above conclusions, the following recommendations are forwarded to curb further spread of the disease in both cattle and human populations:

- Isolation of aborted animals and proper disposal of aborted fetuses and fetal membranes, preferably, by incineration.

- Replacement stock should be purchased from herd known to be free of brucellosis.

- Strict movement control of animal from one area to another in order to prevent the spread and transmission of the disease from infected cattle to the non-infected ones.

- The implementation of test and slaughter policy with compensation payment to the farmers as the prevalence of the disease is low in the study area.

- Adoption of replacement stock vaccination with the aim of eradicating the diseases and prevention of its impact on the public and economic sector.

- Awareness creation among farmers, butchery men, abattoir workers and animal health workers about the nature and effect of the disease through formal and informal educational channels is required.

\section{Material And Methods}

Description of Study Areas

The study was conducted in Holeta Town, Wolmera District and Adea Berga EIAR dairy farm, Oromia regional state, Ethiopia that are known for well-developed dairy production and constituting the major milk sheds of the Addis Ababa. Holeta Town hosts Ethiopian Institute of Agricultural Research dairy farms (Fig. 3).

Source: Diva GIS (Data source) and projected by me using QGIS

Holeta a town of Wolmera District is situated in Oromia special zone surrounding the capital city Addis Ababa. The town is located 29 kilometers west of Addis Ababa at $9^{\circ} 30^{\prime} \mathrm{N}$ and $38^{\circ} 30^{\prime} \mathrm{E}$ with altitude ranging from $2300-3800 \mathrm{~m}$ above sea level which is actually parts of central highlands of Ethiopia. The average annual minimum and maximum temperatures were $6^{\circ} \mathrm{C}$ and $22^{\circ} \mathrm{C}$, respectively. The area is also characterized by occasional frost that occurs in the months of October to December, where temperatures below zero for few days during these months. The annual rainfall ranges from $900-1100 \mathrm{~mm}$. According to the population and housing census of 2007 the population of the town is 23,296 (male $=11512$, female $=11,784)(C S A, 2013)$. The major livestock production systems in the area include: mixed croplivestock farming surrounding the towns, where animals are managed under extensive traditional grazing systems; market oriented, peri-urban dairy production and urban dairy production systems (59). The total cattle population of the study area is estimated to be 175,741 , out of which 172,769 (98.3\%) heads of 
cattle are local breeds and $2972(1.7 \%)$ are cross kept under extensive and semi intensive management systems. Holeta town hosts 11 medium scale dairy farms [60].

Adda Berga located at $9^{\circ} 15^{\prime} 0^{\prime \prime} \mathrm{N}, 38^{\circ} 25^{\prime} 0^{\prime \prime} \mathrm{E}$ is one of the woredas in the Oromia Region of Ethiopia. It hosts Ethiopian Institute of Agricultural Research dairy farm substation. The 2007 national census reported a total population for this woreda of 120,654 , of whom 60,366 were men and 60,288 were women; 15,940 or $13.21 \%$ of its population were urban dwellers. Adea Berga dairy farm was established at Adea Berga wetland in 1986 for commercial milk production under government state farm by using introduced 400 pure Jersey pregnant heifers and 2 sires (foundation stock) from Denmark [61]. The farm had been engaged in the production and rearing of pure Jersey breed from the foundation stock for milk supply for dairy development enterprises and also serve as a bull dam station for the national artificial insemination center (NAIC). Then the farm was transferred to Holeta Agricultural Research Center for genetic improvement research program since 2007. Currently this research dairy farm had 350 pure Jersey, Boran, and Holstein Friesian and Jersey cross breeds kept under semi intensive rearing system.

Study Population

The target study populations were dairy cattle with recent case of abortion in Holeta Town, Wolmera District and large scale dairy farms of Ethiopian Institute of Agricultural Research located in Adea Berga. The occurrence of abortion cases in one month referred to as recent abortion was assessed in the respective site during the entire periods of this study. The dairy cows under study comprised pure Holstein Friesian and Jersey breeds, indigenous breed, and Boran Holstein Friesian and Boran Jersey cross breeds which have no history of vaccination. Study animals related traits such as species, age, body condition score, lactation, reproductive status, parity number; period of abortion and history of abortion were collected and recorded at the time of sampling. Dairy cows were classified into three age groups, $<4$ years, 4-8years and $>8$ years as young, adult and old respectively based on [6]. Body condition score (BCS) was subjectively estimated based on the guides published by Svendsen, (1997).

Employees of the Holeta and Adda Berga Agricultural Research Center dairy farm, dairy cow owners in Holeta Town and Wolmera District who have direct contact with dairy cows and who are willing to participate in the study and sign the informed consent at the age above 18 years old were included.

\section{Study Design}

A cross-sectional study was conducted from November 2019 to May 2020 to study brucellosis in dairy cows with recent history of abortion, and workers of the Holeta and Adda Berga Agricultural Research Center dairy farm and dairy cow owner in Holeta town and Wolmera District who had direct contact with dairy animals.

Sampling Technique and Sample Size Determination

Purposive sampling technique was applied to select medium, large and small scale farms. Accordingly, all eight kebeles, all eleven medium scale and one large scale farm of Ethiopian Institute of Agricultural 
Research of HARC from Holeta Town were included. On the other hand fourteen kebeles out of twenty three kebeles of Wolmera District were selected purposively based on accessibility and number of dairy cows. One large scale farm of Ethiopian Institute of Agricultural Research located in Adda Bberga District was also purposively included in the study.

The sample size for serological study of brucellosis in recently aborted dairy cows was estimated based on the previous study result by [62] in Holeta Town in dairy farms which were $0.92 \%$ seroprevalence. The sample size for the study was calculated using the formula described by [63] with defined precision of 5 $\%$ and $95 \%$ level of confidence interval.

$n=1.96^{2} \times \operatorname{Pex} X(1-P e x)$

$d^{2}$

Where, $n=$ required sample size, $P$ ex $=$ expected prevalence, and $d=$ desired absolute precision

Hence, based on the above formula and taking into account $9.2 \%$ prevalence, the minimum sample size is:

$\mathrm{n}=1.96^{2} \times 0.0092 \times(1-0.0092)$

\section{$(0.05) 2$}

$n=14$

However, in order to increase precision and reduce standard error, all recently aborted cows in the study area during the study duration were included. Therefore, a total of 352 recently aborted cows were sampled in the study duration. On the other hand 149 voluntary animal owners from Holeta Town and Wolmera District and 17 farm employees from Holeta and Adda Berga EIAR dairy farms were also included in the study.

Sample Collection

Blood sample collection

The dairy cows with history of recent abortion were isolated and restrained properly to avoid unexpected personal injury beside to minimizing unnecessary stress that might be happen to the animals. I have been collected blood samples of $7-10 \mathrm{ml}$ after disinfecting the site of jugular vein from each cattle and on the other hand, $5 \mathrm{~mL}$ of blood samples were collected from the cephalic vein of voluntary animal owner and farm workers by a registered nurse in sterile plain vacutainer tubes. The blood samples were kept in a slanting position overnight at room temperature to separate the serum according to [64] manual. Then each serum was gently decanted into sterile screw cupped Eppendorf tubes $(1.8 \mathrm{ml})$, labeled and stored at $-20^{\circ} \mathrm{C}$ in Ethiopian Institute of Agricultural Research (EIAR) Holeta Agricultural Research Center (HARC) 
Animal Health Microbiology laboratory until tested for antibodies against natural Brucella exposure analysis using RPBT and CFT for confirmation of the RBPT positive samples. All serum samples collected from animals were tested for RBPT and CFT in serology laboratory of NVI (National Veterinary Institute), Bishoftu. Serum sample collected from human were screed by RBPT in Holeta Town human Health clinic and confirmed for CFT.

Bacteriological sample collection

Vaginal swab samples were collected according to previous reported work of [65] and the swab was collected with sterile applicator stick in Amies Transport Medium (HiMedia, Mumbai, India) and transported to HARC Microbiology laboratory in cold chain and stored at $-20^{\circ} \mathrm{C}$ until processed for culturing and isolation under Biosafety level III (BSL3) with personal protection (safety measures) according to [64] in Addis Ababa University Pathobiology institute.

Laboratory Diagnosis

Rose Bengal Plate Test (RBPT)

All serum samples collected from bovine and human were screened using RBPT according to the procedures described by Alton et al., (1988), the World Organization for Animal Health [67] and manufacturer's instruction. The antigen used was Rose Bengal antigen, which constitutes a suspension of Brucella. Briefly, for the method, $30 \mu \mathrm{l}$ of serum and $30 \mu \mathrm{l}$ of antigen was mixed on a test plate and rocked for 4 minutes. After four minutes of rocking, visible agglutination was considered as positive. Agglutinations was recorded as $0,+,++$ and +++ , according to the degree of agglutination [68]. A score of 0 indicates the absence of agglutination; + indicates barely visible agglutination; ++ indicates fine agglutination, and +++ indicates coarse clumping. The presence of agglutination was considered positive reaction while the absence of agglutination was considered negative. Brucella positive and negative control sera were also tested along with the test sera to guide in the reading of the results [68]. The results was recorded and stored in Microsoft Excel.

Complement Fixation Test (CFT)

Serum that positive for RBPT were further tested using CFT for confirmation using standard Brucella antigen. Preparation of the reagent was evaluated by titration and performed according to protocols recommended by World Organization for Animal Health [64]. Sera with strong reaction, more than $75 \%$ fixation of complement (3+) at a dilution of $1: 5$ or at least with $50 \%$ fixation of complement $(2+)$ at a dilution of 1:10 and above was considered as positive and lack of fixation/complete hemolysis was considered as negative.

Questionnaire survey

A structured interview question was prepared and applied to all concerned workers of the farm and animal owners who have direct contact with animal and animal products in the study area. Information 
related to personal demography like age, sex, educational background and knowledge, attitude and practice toward brucellosis, raw milk drinking practice, aborted fetus handling practice, history of abortion, chronic headache, Knee pain and testicular swelling were collected on format developed.

The presence of abortion, still births, retention of fetal membranes, separate parturition/maternity pen, and contact between animals with other herds was recorded. Breeding methods was characterized by service types (artificial insemination (Al), bull or both). The method of after birth disposal (placenta, aborted material and dead fetus) was also recorded as burying, ate to dog or thrown to open dump.

Data Management and Analysis

Data collected from field and serological test was coded and stored in Microsoft Office Excel spread sheet and transferred to R. software version 4.0 for statistical analysis. The seroprevalence for animal level was calculated on the basis of RBP and CFT positivity dividing the number of Brucella reactors by total number of tested animals. The Chi-square $(x 2)$ was used to analyze descriptive questioner results and Firth's Bias-Reduced Logistic Regression analysis was employed to identify association of seropositivity with the potential risk factors [63].

\section{Declarations}

Ethics approval and consent to participate

Ethical clearance certificate was obtained from ethical review committee of the animal research of the College of Veterinary Medicine and Agriculture (Date 15/10/2019GC, Ref. No. VM/ER//10/01/12/2020) and Oromia Health Bureau (Date 24/9/2012EC, ReF. No. BEF/HBTFU/146/914) based on the assessment of the research proposal. The standard ethical principles and conducts was implemented both in animal and human study participants. Written and oral informed consents were obtained from human study participants and livestock owners.

\section{Consent for publication}

I am fully agreed that this paper can be published on our journal.

Availability of data and materials

All required data is ready available.

Competing interests

No conflict of interest 
Funding

Funded by Ethiopian Institute of Agricultural Research Holeta Agricultural Research Center Animal Health National Program and Addis Ababa University College of Veterinary medicine and Agriculture

\section{Authors' contributions}

Temesgen Kassa has recorded all the laboratory and survey data, compiling and full write up of the paper, Gezahegni Mammo involved in reviewing and editing of the paper and Beksisa Urge support all the logistics and review the paper.

\section{Acknowledgment}

First of all I would like to thank the Almighty GOD for all his glorious and merciful that always keeps my life confident and peace.

I would like to express my deepest and sincere gratitude to my academic advisor Dr. Gezahegn Mamo (Associate Professor) Addis Ababa University (AAU), College of Veterinary Medicine and Agriculture (CVMA) and his overall research guidance and taking his time to correct this manuscript. I express my heartfelt gratitude to Dr. Beksisa Urge for his support in collecting field data and Dr. Samson Leta for his continued support in data analysis.

My special thanks goes to Ethiopian Institute of Agricultural Research Holeta Agricultural Research Center Animal Health Research Program staff members, and Addis Ababa University, College of Veterinary Medicine and Agriculture (AAU, CVMA), Bishoftu, Ethiopia, academic and support staff members of the college, for their positive cooperation during my research work.

My final gratitude is reserved to my wife Gete Fikadu, and the rest of all my beloved families for their invaluable material and moral support in all facets of life and their constant encouragement to prepare this paper.

\section{Abbreviations}


EIAR Ethiopian institute of agricultural research center

HARC Holeta agricultural research center

LPS Lipopolysaccharide

NK Natural Killer

SAT Serum Agglutination Test

SDA Serum Dextrose Agar

RFM Retained Fetal Membrane

\section{References}

1. Donev D, Karadzovski Z, Kasapinov B, Lazarevik V. Epidemiological and public health aspects of brucellosis in the Republic of Macedonia. Prilozi. 2010;31(1):33-54.

2. Tiller R V, Gee JE, Frace MA, Taylor TK, Setubal JC, Hoffmaster AR, et al. Characterization of Novel Brucella Strains Originating from Wild Native Rodent Species in North Queensland, Australia. JAPPLIED Environ Microbiol. 2010;76(17):5837-45.

3. WHO. Zoonoses and communicable diseases common to man and animals. In: Vol IBacteriosis and Mycosis3rd editionScientific and Technical Publication Washngton, DC, USA,. 2001. p. 187.

4. Pappas G, Papadimitriou P, Akritidis N, Christou L, Tsianos E V. The new global map of human brucellosis. Lancet Infect Dis. 2006;6(February):91-9.

5. Berhe G, Belihu K, In YA-IJ of AR, 2007 U. Seroepidemiological investigation of bovine brucellosis in the extensive cattle production system of Tigray region of Ethiopia. Int J Appl Res Vet Med. 2007;5:6571.

6. Ibrahim N, Belihu K, Lobago F, And MB-TAH, 2010 U. Sero-prevalence of bovine brucellosis and its risk factors in Jimma zone of Oromia Region, South-western Ethiopia. Trop Anim Heal Prod. 2010;42:3540.

7. Eshetu A, Ali A, Mesfin A, Deressa A, Girmaye T. Brucellosis as a zoonosis in chifra district, Afar regional state, Ethiopia. Bull Anim Heal Prod Africa. 2008;56(4):23-30.

8. Edao BM, Hailegebreal G, Berg S, Zewude A, Zeleke Y, Sori T, et al. Brucellosis in the Addis Ababa dairy cattle: the myths and the realities. BMC Vet Res. 2018;14(1):396. 
9. Tolosa T, Bezabih D, Regassa F. Study on Seroprevalence of Bovine Brucellosis and Abortion and associated risk factor. Bull Anim Heal Prod Africa. 2010;58(3):50-9.

10. Megersa B, Biffa D, Abunna F, Regassa A, Godfroid J, Skjerve E. Seroprevalence of brucellosis and its contribution to abortion in cattle, camel, and goat kept under pastoral management in Borana, Ethiopia. Trop Anim Health Prod. 2011;43(3):651-6.

11. Smith MC, Sherman DM. Goat medicine, 32: 189-198. malvern pa. lea, febger. Brucella. Veterinary. 1994;16:196-203.

12. Radostits OM, Gay CC, Hinchcliff KW, Constable PD. Veterinary Medicine: A textbook of the diseases of cattle, horses, sheep, pigs and goats. Saunders Ltd. 2007.

13. Svendsen E. Parasites Abroad in: The professional hand book of the donkey. Svendsen, E.D. (Ed.). 3rd Edition, Whittet Books, London. 227-238. 1997;

14. Bashitu L, Afera B, Tuli G, Aklilu F. SeroPrevalence study of bovine brucellosis and its associated risk factors in Debrebirhan and ambo towns. J Adv Dairy Res. 2015;3(131):2.

15. Alem W, Solomon G. A retrospective sero-epidemiology study of Bovine Brucellosis in different Production Systems in Ethiopia. In: Proceeding of 16th annual conference. 2002. p. 53-7.

16. Radostits O, Otto MR, Radostis OM, Gay CC, Hinchcliff KW. Veterinary medicine: a textbook of the diseases of cattle, sheep, pigs, goats and horses. WB Saunders Comapany Ltd. 2000;9:1046-58.

17. Tesfaye A. Brucellosis in cattle and small ruminants in selected sites of Tigray Region, North Ethiopia. DVM Thesis FVM AAU Debre Zeit Ethiop. 2003;

18. Tolosa T, Regassa F, Belihu K. Seroprevalence study of bovine brucellosis in extensive management system in selected sites of Jimma Zone, Western Ethiopia. Bull Anim Heal Prod Africa. 2008;56(1):25-37.

19. Gumi B, Firdessa R, Yamuah L, Sori T, Tolosa T, Aseffa A, et al. Seroprevalence of brucellosis and Qfever in southeast Ethiopian pastoral livestock. J Vet Sci Med Diagn. 2013;2(1).

20. Adugna KE, Agga GE, Zewde G. Seroepidemiological survey of bovine brucellosis in cattle under a traditional production system in western Ethiopia. Rev Sci Tech. 2013;32(3):765-73.

21. Kang'Ethe EK, Ekuttan CE, Kimani VN, Kiragu MW. Investigations into the prevalence of bovine brucellosis and the risk factors that predispose humans to infection among urban dairy and non-dairy farming households in Dagoretti Division, Nairobi, Kenya. East Afr Med J. 2007;84(11 Suppl):S96-100.

22. Jergefa T, Kelay B, Bekana M, Teshale S, Gustafson H, Kindahl H. Epidemiological study of bovine brucellosis in three agro-ecological areas of central Oromiya, Ethiopia. Rev Sci Tech. 2009;28(3):933. 
23. Degefu $\mathrm{H}$, Mohamud M, Hailemelekot M, Yohannes M. Seroprevalence of bovine brucellosis in agro pastoral areas of Jijjiga zone of Somali National Regional State, Eastern Ethiopia. Ethiop Vet J. 2011;15(1):37-47.

24. Haileselassie M, Kalayou S, Kyule M, Asfaha M, Belihu K. Effect of Brucella infection on reproduction conditions of female breeding cattle and its public health significance in Western Tigray, northern Ethiopia. Vet Med Int. 2011;2011:7.

25. Megersa B, Biffa D, Niguse F, Rufael T, Asmare K, Skjerve E. Cattle brucellosis in traditional livestock husbandry practice in Southern and Eastern Ethiopia, and its zoonotic implication. Acta Vet Scand. 2011;53(1):24.

26. Asmare K, Sibhat B, Molla W, Ayelet G, Shiferaw J, Martin AD, et al. The status of bovine brucellosis in Ethiopia with special emphasis on exotic and cross bred cattle in dairy and breeding farms. Acta Trop. 2013;126(3):186-92.

27. Tibesso G, Ibrahim N, Tolosa T. Sero-prevalence of bovine and human brucellosis in Adami Tulu, central Ethiopia. World Appl Sci J. 2014;31(5):776-80.

28. Geresu MA, Ameni G, Tuli G, Arenas A, Kassa GM. Seropositivity and risk factors for Brucella in dairy cows in Asella and Bishoftu towns, Oromia Regional State, Ethiopia. 2016;10(7):203-13.

29. Omer MK, Skjerve E, Woldehiwet Z, Holstad G. Risk factors for Brucella spp. infection in dairy cattle farms in Asmara, State of Eritrea. Prev Vet Med. 2002;46(4):257-65.

30. Angara TEE, Ismail AA, Agab H, Saeed NS. Sero-prevalence of bovine brucellosis in Kuku Dairy Scheme, Khartoum North, Sudan. 0. 2004;0.

31. Matope G, Bhebhe E, Muma JB, Lund A, Skjerve E. Risk factors for Brucella spp. infection in smallholder household herds. Epidemiol Infect. 2011;139(1):157-64.

32. Mai HM, Irons PC, Kabir J, Thompson PN. A large seroprevalence survey of brucellosis in cattle herds under diverse production systems in northern Nigeria. BMC Vet Res. 2012;8(1):144.

33. Swanepoel R, Coetzer JAW, Tustin RC. Infectious diseases of livestock with special reference to southern Africa. 2004;

34. Aparicio ED. Epidemiology of brucellosis in domestic animals caused by Brucella melitensis, Brucella suis and Brucella abortus. Rev sci tech Off int Epiz. 2013;32(1):53-60.

35. Kebede T, Ejeta G, Ameni G. Seroprevalence of bovine brucellosis in smallholder farms in central Ethiopia (Wuchale-Jida district). Rev Med Vet (Toulouse). 2008;159(1):3. 
36. Walker RL. Brucella. In: Dwight C. Hirsh and Yuang Chung Zee (ED.): Veterinary Microbiology. USA: Blackwell Science Inc. Vet Microbiol. 1999;196:Pp.196-203.

37. Silva I, Dangolla A, Kulachelvy K. Seroepidemiology of Brucella abortus infection in bovids in Sri Lanka. Prev Vet Med. 2000;46(1):51-9.

38. Kagumba M, Nandokha E. A survey of the prevalence of bovine brucellosis in East Africa. Bull Anim Health Prod Afr. 1978;26(3):224.

39. Mugizi D. Relationship between bovine brucellosis and production systems in Kashongi sub-county of Kiruhura-Uganda. Bull Anim Heal Prod Africa. 2009;57(3):209-19.

40. Adesokan HK, Alabi PI, Stack JA, Cadmus SIB. Knowledge and practices related to bovine brucellosis transmission amongst livestock workers in Yewa, south-western Nigeria. J S Afr Vet Assoc. 2013;84(1):1-5.

41. Tolosa T. Seroprevalence study of bovine brucellosis and its public health significance in selected sites of Jimma Zone, Western Ethiopia. Ethiop Msc Thesis, Addis Ababa Univ Fac Vet Med Debre Zeit. 2004;

42. Hailemelekot M, Kassa T, Asfaw Y. Seroprevalence study of brucellosis in Bahirdar milkshed, Northwestern Amhara Region. Ethiop Vet J. 2007;11:49-65.

43. Gebawo T, Ibrahim N, Tolosa T. Sero-prevalence of bovine and human brucellosis in Adami Tulu, central Ethiopia. World Appl Sci J. 2014;31(5):776-80.

44. Mugabi R. Brucellosis epidemiology, virulence factors, control and molecular targets to prevent bacterial infectious diseases. 2012;

45. Miller R, Nakavuma JL, Ssajjakambwe P, Vudriko P, Musisi N, Kaneene JB. The prevalence of brucellosis in cattle, goats and humans in rural Uganda: a comparative study. Transbound Emerg Dis. 2016;63(6):e197-210.

46. Mukhtar F, Kokab F. Brucella Serology in Abattoir Workers. J Ayub Med Coll Abbottabad. 2008;20(3):57-61.

47. Bishop G, Bosman P, S Herr. Infectious Diseases of Livestock with Special Reference to Southern Africa, J.A.W. Coetzer, G.R. Thomson and R.C. Tustin (Editors), Oxford University Press,. 1994. 1053-1066 p.

48. Kassahun A. Epidemiology of bovine brucellosis in cattle and its seroprevalence in animal health professionals in Sidama Zone, Southern Ethiopia. Master Sci thesis Addis Ababa Univ Fac Vet Med Debre Zeit, Ethiop. 2004; 
49. Tadelle T. Faculty of veterinary medicine a retrospective study on the impact of community based animal health service delivery system in shinile zone, somali national regional state of Ethiopia $A$ thesis submitted to the faculty of Veterinary Medicine, Addis Ababa. 2004;

50. Mussie HM. Seroprevalence study of bovine brucellosis in cattle and humans in Bahir Dar Milk shade. Master Sci thesis Addis Ababa Univ Fac Vet Med Debre Zeit, Ethiop. 2005;

51. Haddad Q, Smith SR. Current experience with brucellosis at security-forces-hospital, riyadh. Ann Saudi Med. 1986;6(4):S11-4.

52. Kassahun J, Yimer E, Geyid A, Abebe P, Newayeselassie B, Zewdie B, et al. Sero-prevalence of brucellosis in occupationally exposed people in Addis Ababa, Ethiopia. Ethiop Med J. 2006;44(3):24552.

53. Prilutski M. Joining the World of Journals Celebrating Student Research. J Undergra Res. 2010;1:51-8.

54. Regassa G, Desalew M, Yamuah L, Hiwot T, Teshome G, Asfawesen G, et al. Human brucellosis in traditional pastoral communities in Ethiopia. Int J Trop Med. 2009;4(2):59-64.

55. Tuli G, Tsegay A, Kassa T, Kebede N. Seroprevalence and risk factors of brucellosis in abattoir workers at Debre Zeit and Modjo export abattoir, Central Ethiopia. BMC Infect Dis. 2017;17(1):101.

56. Lindahl E, Sattorov N, Boqvist S, Magnusson U. A study of knowledge, attitudes and practices relating to brucellosis among small-scale dairy farmers in an urban and peri-urban area of Tajikistan. PLoS One. 2015;10(2).

57. Mussie H, Tesfu K, Yilkal A. Seroprevalence study of bovine brucellosis in Bahir Dar Milk shed, Northwestern Amhara Region. Ethiop Vet J. 2007;11:42-9.

58. CSA. 2007 POPULATION and HOUSING CENSUS OF ADMINISTRATIVE. 2007.

59. CSA. Ethiopian Livestock sector current status and future prospects Introduction: Livestock production. 2016;

60. WoWAHA. WolmeraWereda Animal Health Agency. StatisticalAbstract. Wolmera, FinfineLiyuZuria Zone, Oromia, Ethiopia. Academic Journals; 2015.

61. Siyoum T, Yohannes A, Shiferaw Y, Asefa E, Melese E. Major reproductive disorders on Jersey breed dairy cattle at Adea Berga dairy farm , West Shewa Zone ,. Ethiop Vet J. 2016;20(1):91-103.

62. Shanko K. Sero- epidemiological study of bovine brucellosis in selected dairy farms of bishoftu and holeta towns, oromia regional state, central Ethiopia. Thesis Addis Ababa Univ. 2017;50.

63. Thrusfield M. Sample size determination. Vet Epidemiol. 2007;3:185-9. 
64. OIE. Bovine brucellosis, world organisation for animal health manual of diagnostic tests and vaccines (mammals, birds and bees ) Sixth Edition. Vol. 2. 2009.

65. Geresu MA, Ameni G, Wubete A, Arenas-Gamboa AM, Gezahegne MK. Isolation and Identification of Brucella Species from Dairy Cattle by Biochemical Tests: The First Report from Ethiopia. World Vet J. 2016;6(2):80-8.

66. Alton $\mathrm{G}$, Jones L, Angus R, J Verger. Techniques for the brucellosis laboratory. Institute National de la Recherche, Agronomique, Paris, France. 1988. p. 81-134.

67. OIE. Manual of Diagnostic Tests and Vaccines for Terrestrial Animals.5th Ed. Office International des Epizooties, Paris, France,. OIE. Office international des épizooties; 2004. 409-438 p.

68. Nielsen K, Duncan JR. Animal Brucellosis [Internet]. Taylor \& Francis; 1990. 173-179 p. Available from: https://books.google.com.et/books?id=QQFDHBpNnTQC

\section{Figures}

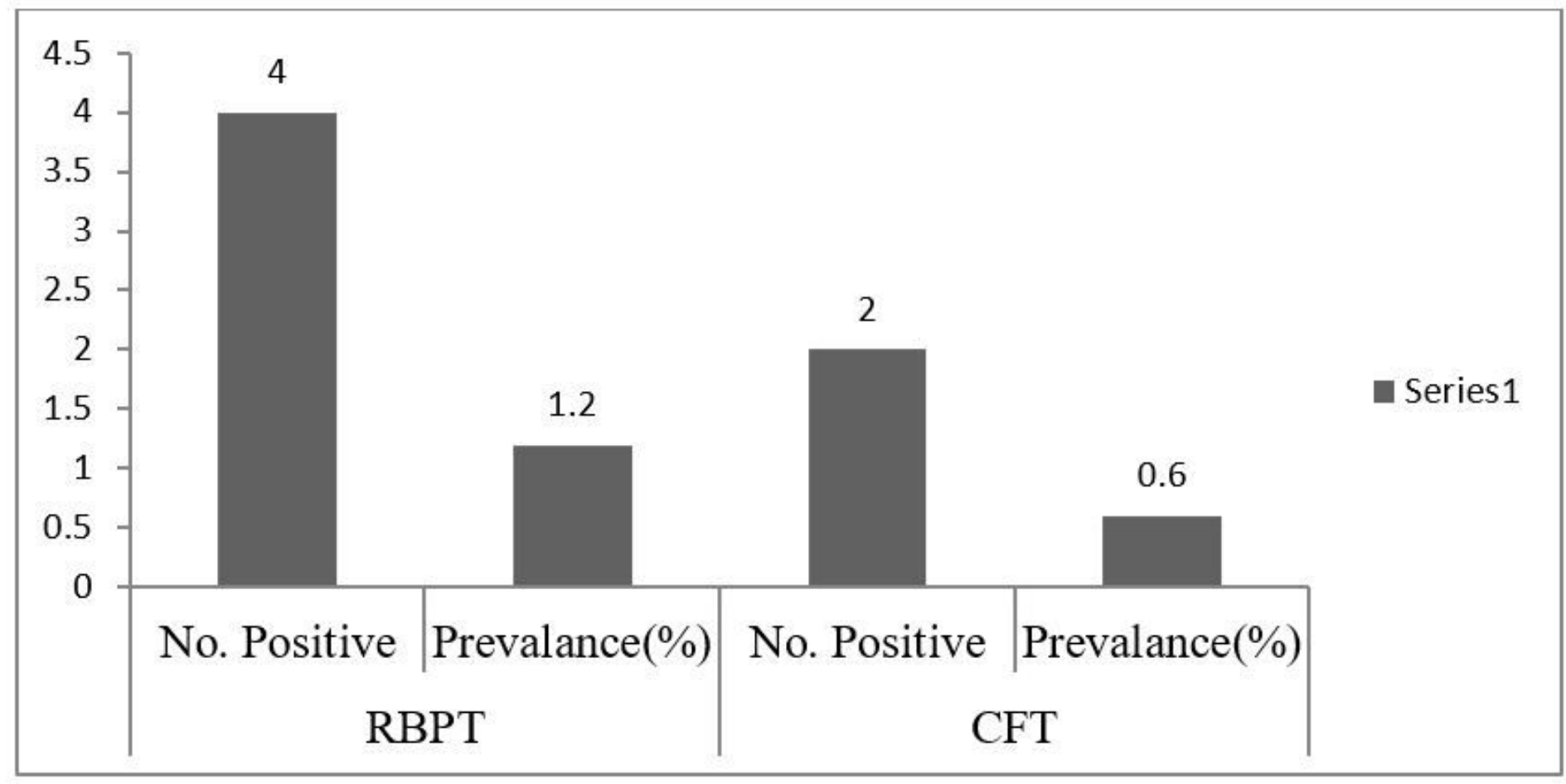

\section{Figure 1}

The overall seroprevalence of brucellosis in dairy cow with a history of recent abortion by RBPT and CFT diagnostic techniques 


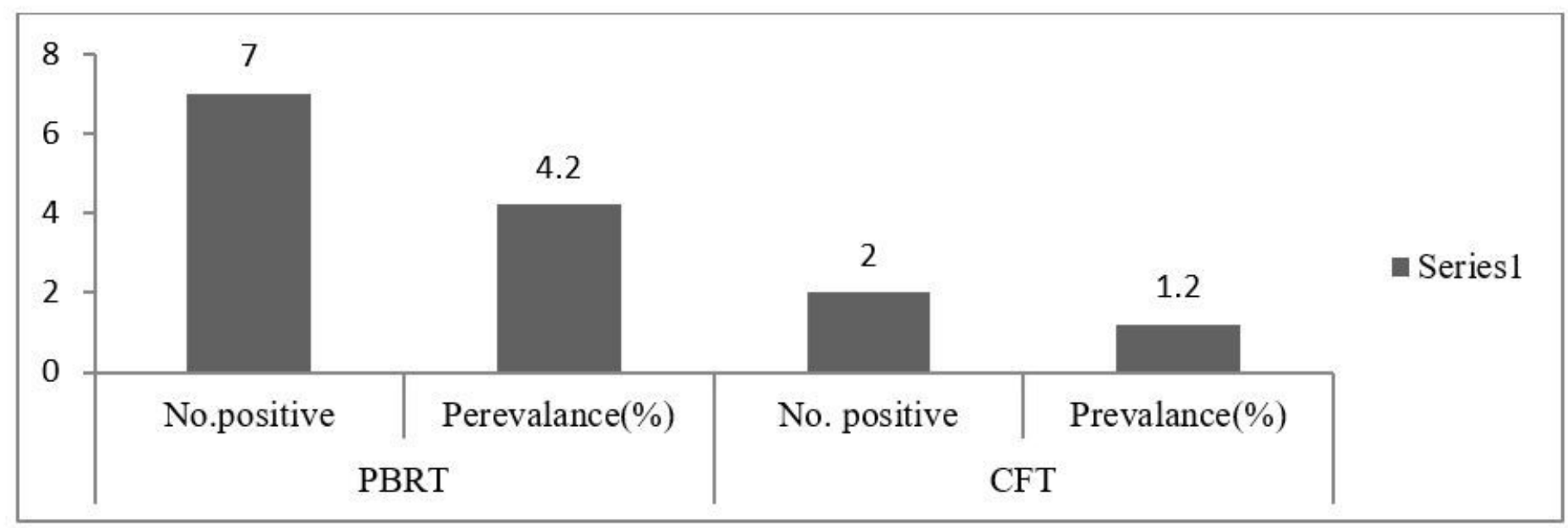

Figure 2

The overall seroprevalence of brucellosis in dairy cattle owners and dairy farm workers with combined RBPT and CFT diagnostic techniques

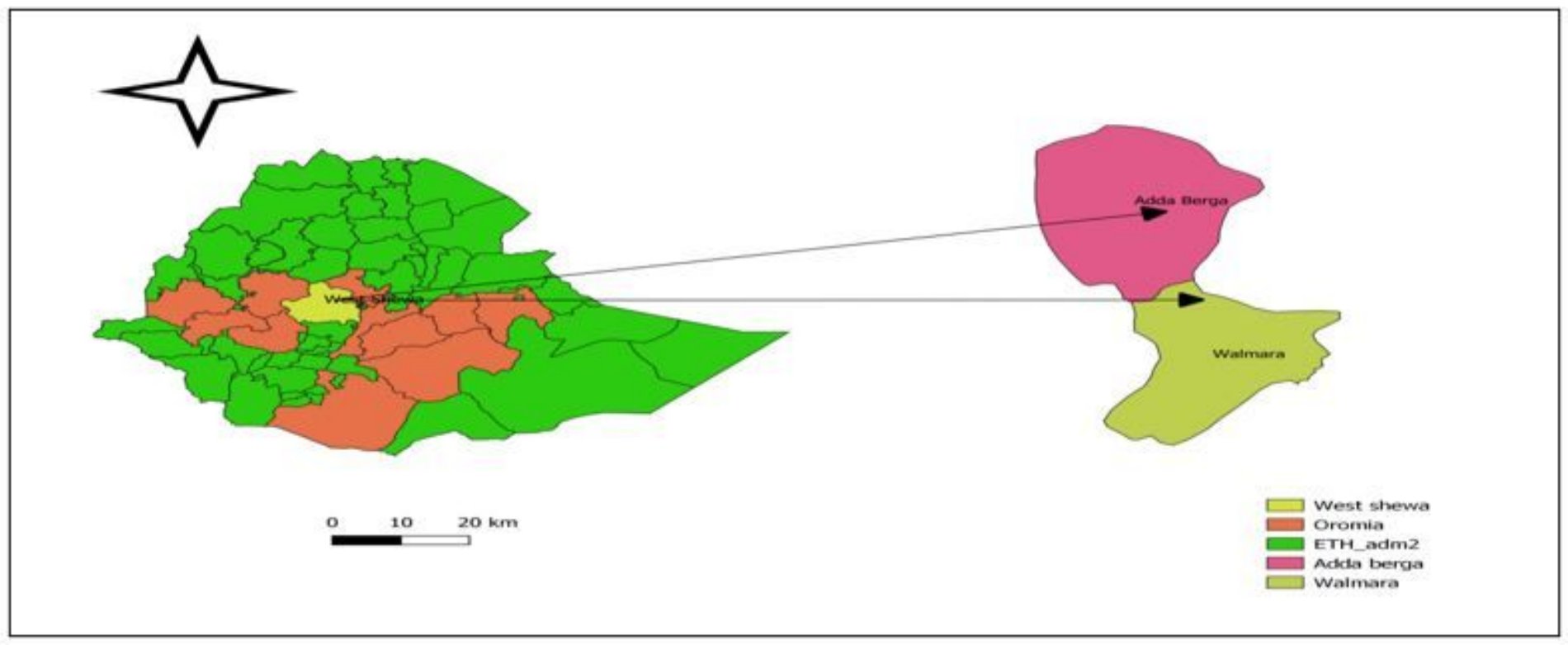

Figure 3

Wolmera and Addea Berga Districts Oromia regional state, Ethiopia Source: Diva GIS (Data source) and projected by me using QGIS

\section{Supplementary Files}

This is a list of supplementary files associated with this preprint. Click to download.

- Ethicsapprovalandconsenttoparticipate.docx

- Ethicsapprovalandconsenttoparticipate.docx 
Page $41 / 41$ 